\title{
Patterns in flight phenologies of bark beetles (Coleoptera: Scolytinae) in commercial pine tree plantations in Uruguay
}

\author{
Estacionalidad de vuelo de escarabajos de corteza (Coleoptera: Scolytinae) \\ en plantaciones comerciales de pino en Uruguay
}

\author{
Demian Gómez a*, Andrés Hirigoyen a, Gustavo Balmelli a, Carmen Viera b, Gonzalo Martínez a \\ *Autor de correspondencia: ${ }^{a}$ INIA, Programa Nacional de Producción Forestal, Tacuarembó, Uruguay, \\ tel.: +598 4632 2407, demiangz@gmail.com

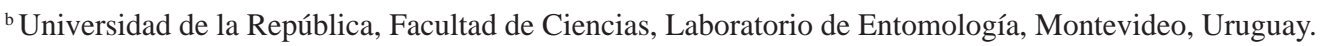

\begin{abstract}
SUMMARY
The increasing forested area in Uruguay facilitates the establishment of exotic bark and ambrosia beetles. In 2009, the first infestation of bark beetles was officially recorded. The outbreak included Hylurgus ligniperda, Cyrtogenius luteus and Orthotomicus erosus. The objective of this study was to describe and compare the seasonal flight activity and development time of bark beetles in Pinus taeda commercial stands. Flight activity was monitored by placing interception traps from July 2012 to July 2013 . Every 15 days, beetles were collected. Development time was assessed with sets of trap logs from June 2013 to June 2014 during every season. A fortnight after the presence of colonization signs was verified, trap logs were taken to the lab to be incubated. Among the three species of bark beetles captured, $H$. ligniperda was the most abundant, representing $57 \%$ of the total captures, followed by O. erosus (30\%) and C. luteus (12\%). Hylurgus ligniperda was captured throughout the monitoring period, showing flight peaks during fall and winter. On the other hand, captures of $O$. erosus were recorded mostly during spring and summer. Cyrtogenius luteus was captured exclusively during high temperature periods. For all species recorded, log colonization date varied through seasons matching the flight period. Incubation time was strongly influenced by temperature, with shorter generations in high temperature periods. Correspondingly, differences in the duration of the subcortical phase were observed for the three species. Our study provided valuable information that can be used to adjust pruning and thinning schedules by forestry companies.
\end{abstract}

Key words: bark beetles, flight phenology, commercial pine tree, Uruguay.

\section{RESUMEN}

El incremento de área forestada en Uruguay facilita el establecimiento de escarabajos de corteza y de ambrosia exóticos. En 2009 se reportó el primer brote de escarabajos de corteza, que incluyó a Hylurgus ligniperda, Cyrtogenius luteus y Orthotomicus erosus. El objetivo del trabajo fue describir y comparar la actividad estacional de vuelo y el tiempo de desarrollo de estos insectos en plantaciones comerciales de Pinus taeda. La actividad de vuelo fue monitoreada mediante trampas de intercepción (julio 2012 a julio 2013) y recolección cada 15 días. El tiempo de desarrollo se evaluó utilizando trozas cebo durante cada estación (junio 2013 a junio 2014 ). Quince días después de observados los signos de colonización, las trozas cebo fueron llevadas al laboratorio para incubación. Hylurgus ligniperda fue la especie más abundante (57 \% de las capturas), seguida por O. erosus (30 \%) y C. luteus (12 \%). Hylurgus ligniperda fue capturado durante todo el período de monitoreo, con picos de vuelo durante otoño e invierno. Orthotomicus erosus fue registrado mayormente durante primavera y verano. Cyrtogenius luteus fue capturado exclusivamente durante períodos de alta temperatura. Para estas especies, la fecha de colonización de trozas varió entre estaciones, concordando con el período de vuelo. El tiempo de incubación fue influenciado por la temperatura, con generaciones más cortas en períodos de alta temperatura. También hubo diferencias en la duración de la fase subcortical en las tres especies. Este estudio provee información valiosa que puede ser utilizada para ajustar calendarios de poda y raleo en empresas forestales.

Palabras clave: escarabajos de corteza, fenología de vuelo, plantaciones comerciales de pino, Uruguay.

\section{INTRODUCTION}

Large scale forestry with pine tree started in 1940 in Uruguay with Pinus radiata Don. In 1950, seeds of P. taeda L. and P. elliottii Engelm., among others, were brought from the United States and became the most planted species in commercial pine tree plantations, reaching $25 \%$ of the total forested area (257.000 ha) in Uruguay in the last decades (DIEA 2013). The majority of the pine tree plantations are located in the northern part 
of the country, where they are managed to produce high quality timber.

The increasing forested area in Uruguay, concurrently with the growth of the international trade, facilitates the establishment of exotic pests and diseases. In particular, the international flow of wood packing and plant material may increase the risk of colonization by bark and ambrosia beetles, which are considered one of the most dangerous pests in implanted and native forests worldwide. These insects not only attack stressed trees, but some species also develop and kill healthy hosts during epidemic outbreaks (Sauvard 2004).

The red-haired bark beetle Hylurgus ligniperda (F.) (Scolytinae: Tomicini) was the only Scolytinae listed for pine tree plantations in the country before 2012 (Ruffinelli 1967). This European insect has successfully established in South America (Argentina, Brazil, Paraguay, Uruguay and Chile), North America, Australia and New Zealand (Haack 2006, Wood 2007). It is a multivoltine species with up to 4 generations per year in Chile (Ruiz and Lanfranco 2008). It breeds in stumps or slash material and usually attacks stressed stands at the base of the tree (Eglitis 2001). Until recently, $H$. ligniperda had been related to dead trees, stumps or slash material with no economic significance (Bentancourt and Scatoni 2010). However, in 2009 , the first infestation of bark beetles in commercial stands was officially reported to the Ministry of Livestock, Agriculture and Fishery of Uruguay (Gómez et al. 2012). The outbreak not only included $H$. ligniperda but also two new records for the country: Cyrtogenius luteus (Blandford) (Scolytinae: Dryocetini) and Orthotomicus erosus Wollaston (Scolytinae: Ipini). Cyrtogenius luteus is native to Asia where it attacks dying or dead trees, with no economic significance. It was introduced into Italy and Uruguay in 2009 (Faccoli et al. 2012, Gómez et al. 2012). In Uruguay, C. luteus has been found in several infested areas, including dead trees of P. taeda (Gómez et al. 2012). Orthotomicus erosus is native to Europe, Asia, and North Africa. It is a multivoltine species in its native region with 2-7 generations per year, depending on local temperatures (Mendel 1983). It breeds in recently fallen or cut pine trees and branches but also kills living trees under stress. This species is considered an important pest from Europe and has been included in quarantine lists in several countries worldwide (USDA 1993, Ruiz and Lanfranco 2008). On its native range, $P$. pinaster is the preferred host of $O$. erosus (Baylis et al. 1986). Although in Uruguay damage caused by this species has been also recorded on other species of Pinus, some plantations of $P$. pinaster suffered more than $80 \%$ of tree mortality in 2009. Nowadays, these three species are found all around the country in commercial plantations of P. taeda, P. elliottii and P. pinaster Aiton (Gómez 2012, Gómez and Martínez 2013). Hence, it becomes relevant to understand their seasonal activity.

These new records confirm a regional trend of increasing invasion by bark beetles (Gómez 2008, Gómez et al. 2012, Gómez and Martínez 2013, Klasmer and Diez de Ulzurrún 2013). In spite of the undeniable economic importance of these taxa for pine tree forestry, basic ecological studies of the recorded species are still to be done in Uruguay. Moreover, all the data from bordering countries are not transferable to Uruguay due to climatic variability and tree species planted. In particular, knowing seasonal phenology of recently introduced bark beetles is essential to develop silvicultural control and minimize the damage of these insects. The objective of this study is to describe the seasonal flight activity and development time of the three bark beetles recorded in P. taeda commercial stands using window interception traps and trap logs. We hypothesize that the species recorded will present different flight periods, which will not necessarily be the same as those they have in their place of origin.

\section{METHODS}

Site. The study was conducted in a commercial plantation of P. taeda ("La Corona") located in Tacuarembó, Uruguay (3136’37.97” S; 55²3’38.32” W). Uruguay has a subtropical to temperate climate with seasonal fluctuations (FAO 2001). Mean temperature during summer and winter for the past ten years was $23.5^{\circ} \mathrm{C}$ and $12{ }^{\circ} \mathrm{C}$, respectively (INUMET 2015). The stand was planted in 1998 at an original density of 1,100 trees per hectare and had 450 trees per hectare when the experiment was conducted. It was surrounded by other $P$. taeda stands. The site was chosen because of the availability of slash material suitable as host.

Flight activity. Flight activity of bark beetles was monitored by placing three interception traps in a straight line at $1 \mathrm{~km}$ interval. Each interception trap consists in a $120 \mathrm{~cm}$ by $50 \mathrm{~cm}$ wooden frame with transparent glass and two plastic containers, one on each side of the frame, similar to that used by Soto et al. (2002). Collection containers were filled half-way with ethylene glycol solution as a killing and preservative agent. The traps were baited with four P. taeda logs ( $1 \mathrm{~m}$ long and $0.1 \mathrm{~m}$ in diameter). Every 15 days, beetles were collected and logs were replaced. Collections began in July 2012 and ended in July 2013, resulting in 24 collecting dates. All captured insects were kept in $70 \%$ alcohol until examination and then deposited in the Forest Entomological Collection of INIA in Tacuarembó, Uruguay.

Flight activity of each species was determined based on the total number of individuals trapped. Number of catches were plotted and compared from July 2012 to July 2013. Flight seasonality for each species was determined based on the percentage of seasonal catches throughout the year. Temperature was recorded with a Hygrochron 1923F5 data logger at 6 hours intervals and daily temperature data were disposed as 15-day averages to coincide with the trapping regime. 
Trap log study. Bark beetle development time was studied from June 2013 to June 2014, when three sets of five trap logs for incubation (1 $\mathrm{m}$ long and $0.2 \mathrm{~m}$ in diameter) were cut from $P$. taeda trees during summer, fall, winter and spring. The logs were stacked horizontally on thin dry branches to reduce contact with the soil and avoid humidity. Trap logs were checked daily for entrance holes, frass piles or beetles boring into the bark. A fortnight after the presence of colonization signs was verified, trap logs were taken to the lab to be incubated in sheltered weather conditions inside cylindrical white plastic cages $(1 \mathrm{~m}$ tall and $0.6 \mathrm{~m}$ diameter) covered with voile fabric. The cages were checked for emergencies three times a week until no more beetles emerged. The number of weeks required in order to complete the subcortical phase of the life cycle for each species was determined. The mean number of beetles emerging from the logs per week in every season was recorded and plotted. Only logs with emergences were considered for the study.

\section{RESULTS}

Flight activity. A total of 7,673 scolytids were captured during the 12 month of monitoring. Catches of bark beetles represented $98.9 \%$ of the scolytids (7,573 specimens), while ambrosia beetles represented $1.1 \%$ of the total. Among the three species of bark beetles captured, $H$. ligniperda was the most abundant representing $57 \%$ of the total captures, followed by O. erosus (30 \%) and C. luteus (12\%). Ambrosia beetles captured were identified as Xyleborus ferrugineus (F.) and Xyleborinus saxesenii (Ratzeburg), and were represented by 59 and 41 individuals, respectively.

Captures of bark beetles suggest that the three species differ in their population dynamics (figure 1). A total of 4,400 specimens of $H$. ligniperda were captured throughout the monitoring period, showing flight peaks during fall and winter (figure 1A). Most of the captures (75\%) were recorded during May and August, with flights occurring when mean temperatures fluctuated between 14 and

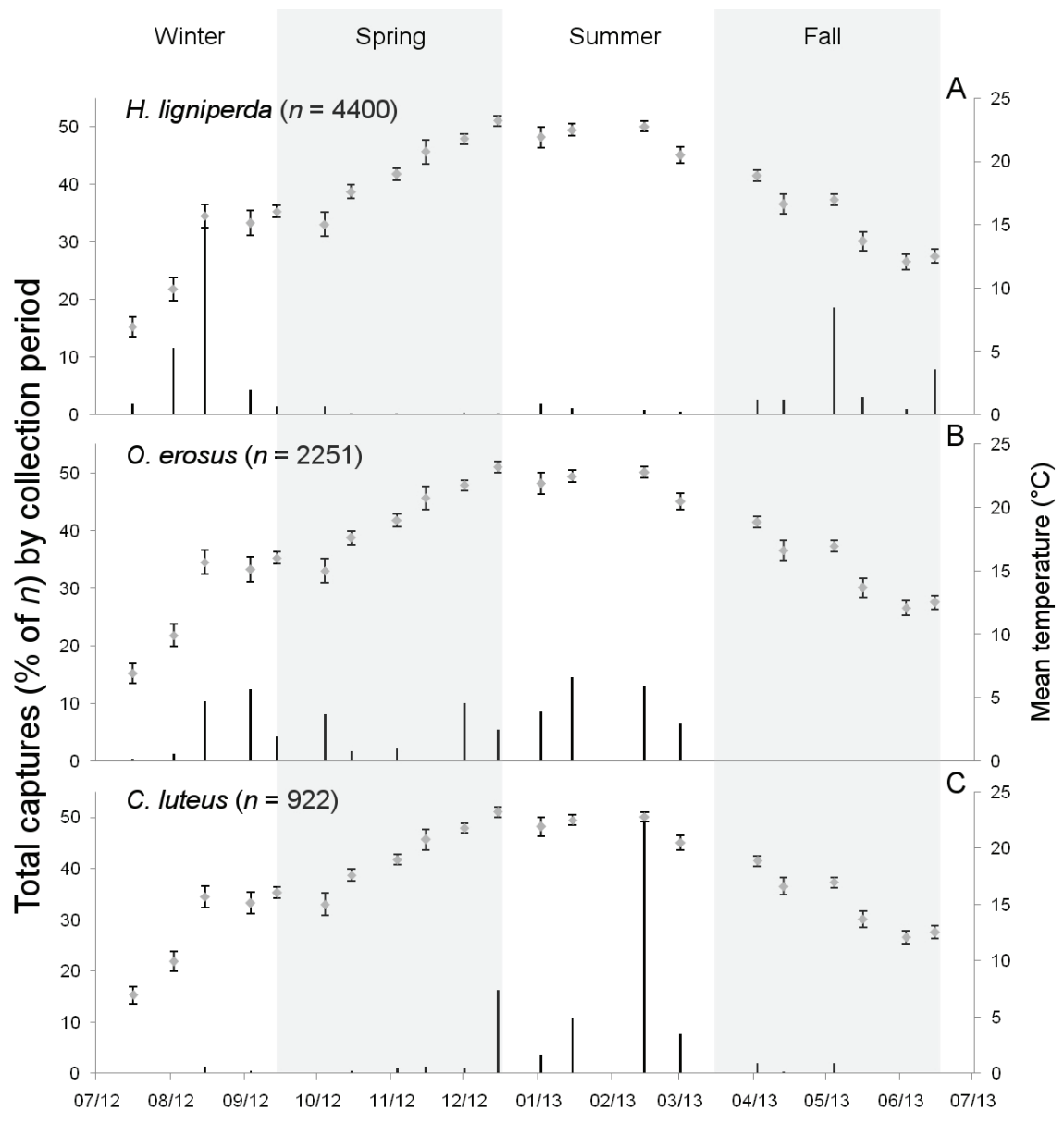

Figure 1. Total captures (\% of $n$ ) of Hylurgus ligniperda (A), Orthotomicus erosus (B) and Cyrtogenius luteus (C) in interception traps in Tacuarembó, Uruguay (traps were set from 7 July 2012 to 7 July 2013), with mean temperatures \pm SEM at two week intervals.

Capturas totales (\% of $n$ ) de Hylurgus ligniperda, Orthotomicus erosus y Cyrtogenius luteus en trampas de intercepción en Tacuarembó, Uruguay (trampas colocadas desde el 7 de julio de 2012 al 7 de julio de 2013), con temperaturas medias \pm SEM en intervalos de dos semanas. 
$17^{\circ} \mathrm{C}$. Flights of this species declined during higher temperature periods (between October and April) with very low flight activity during summer. On the other hand, captures of $O$. erosus were recorded mostly during late winter, spring and summer, when $91 \%$ of the 2,251 specimens were captured (figure 1B). Flight activity peaked on midAugust and February, when mean temperature fluctuated between 17 and $22{ }^{\circ} \mathrm{C}$. Low activity during fall and winter was observed for this species, with only $9 \%$ of the captures during this period. A total of 922 specimens of $C$. luteus were captured exclusively during high temperature periods (figure 1C). Captures between December and February represented $90 \%$ of the total. The activity peak occurred during February when the mean temperature reached $22^{\circ} \mathrm{C}$.

Trap log study. Colonization time, details of the incubation and mean emerged specimens are shown in table 1. For all species recorded, log colonization date varied through seasons matching the flight period (table 1). Incubation time was strongly influenced by temperature, with shorter generations in high temperature periods. Correspondingly, differences in the duration of the subcortical phase were observed for the three species (figure 2).

Emergences from winter colonization were only recorded for $H$. ligniperda, from early November (week 19) to late December (week 25). Emergence peak occurred during week 21 (figure 2). Emergences from spring colonization corresponded to O. erosus and H. ligniperda. Hylurgus ligniperda emerged during December and early January (from week 11 to week 16), with an emergence peak on week 12 and 13 (figure 2). Emergences of O. erosus occurred from late November to December (from week 10 to week 15), with an emergence peak on week 12 (figure 2). Emergences from summer colonization corresponded mostly to C. luteus, while O. erosus was barely recorded. During this season, C. luteus started to emerge in March (week 9) and continued to emerge until early April (week 12), with an emergence peak during week 11 (figure 2). When the colonization took place during fall, only $H$. ligniperda emerged, from September (week 22) to December (week 36), with an emergence peak on week 24.

\section{DISCUSSION}

The present study provided, for the first time, information on the seasonal activity by three exotic bark beetles species recorded in pine tree plantations in northern Uruguay. Both activity peaks for $H$. ligniperda registered in Uruguay during fall and winter are in line with data from France and New Zealand, where the first generation of adults oviposits during winter and spring, and a second generation lays eggs in fall (Reay and Walsh 2001). Observations from South Africa suggest the occurrence of four generations per year, with flight peaks during fall, spring and summer (Tribe 1991). Results from our incubation study showed that in Uruguay, it takes at least six months to complete the subcortical phase after fall colonization and at least four months after winter colonization, recording the first emergences in early or mid-spring, respectively. This long developing time is explained by the low temperature in most part of the life cycle as well as the sheltered weather conditions that prevent heat accumulation. On the other hand, the subcortical phase lasts only 2.5 month when the colonization occurs in spring; first emergences being recorded in early summer. Thus, $H$. ligniperda may present at least two generations per year. Fall flight activity results in one generation which would emerge at early spring, overwintering as late larvae or pupae. Winter and early spring flight activity results in a second generation in summer or fall season. There was no log colonization during summer, therefore, the small activity peaks of $H$. ligniperda during this season suggest new reproductive galleries with low or non-dispersion rates. Data from Chile suggest one or two activity peaks during the year, with no generation number associated (Mausel et al. 2007). The authors suggest the overlap of generations with fertilized females ovipositing in the same host if it is still suitable for a new maternal gallery.

Flight activity of $O$. erosus occurred during late winter, spring and summer. These results are similar to those reported from Europe, Israel, South Africa and Tunisia (Mendel 1983, Tribe 1990). Mendel (1983) reports seven possible annual generations for this species, with 30 days

Table 1. Colonization and incubation of bark beetles during the trap log study in "La Corona”, Tacuarembó.

Colonización e incubación de escarabajos de corteza durante el estudio de trozas cebo en “La Corona”, Tacuarembó.

\begin{tabular}{|c|c|c|c|c|c|c|c|}
\hline \multirow[b]{2}{*}{ Season } & \multirow[b]{2}{*}{ Log cut date } & \multirow{2}{*}{$\begin{array}{l}\text { Colonization } \\
\text { (days) }\end{array}$} & \multirow{2}{*}{$\begin{array}{c}\text { Mean } \\
\text { temperature of } \\
\text { incubation }\left({ }^{\circ} \mathrm{C}\right)\end{array}$} & \multirow{2}{*}{$\begin{array}{l}\text { Start of } \\
\text { emergence } \\
\text { (weeks) }\end{array}$} & \multicolumn{3}{|c|}{ Mean emergence (individuals per log \pm SEM) } \\
\hline & & & & & $\begin{array}{c}\text { Hylurgus } \\
\text { ligniperda }\end{array}$ & $\begin{array}{c}\text { Orthotomicus } \\
\text { erosus }\end{array}$ & $\begin{array}{c}\text { Cyrtogenius } \\
\text { luteus }\end{array}$ \\
\hline Winter & $17-06-13$ & 16 & 19.2 & 19 & $220 \pm 30.4$ & 0 & 0 \\
\hline Spring & $13-09-13$ & 10 & 23.4 & 11 & $305 \pm 128.1$ & $128 \pm 6.8$ & $17 \pm 1.7$ \\
\hline Summer & $13-01-14$ & 7 & 24.1 & 9 & 0 & $5 \pm 0.5$ & $829 \pm 224.8$ \\
\hline Fall & $10-04-14$ & 12 & 15.7 & 22 & $96 \pm 16.5$ & 0 & 0 \\
\hline
\end{tabular}


to develop. In Uruguay, spring colonization suggests that O. erosus needs two to three month to complete the subcortical phase starting to emerge in late spring. The individuals emerging in late spring would colonize new host material for breeding. Very few emergences of $O$. erosus were observed during summer colonization, probably due to very low flight activity of this species during early 2014. Our results suggest at least two generations per year in Uruguay. It is important to note however, that more gene- rations per year may occur, provided the continuous flight activity observed as well as the ability to overwinter as larvae (Mendel 1983).

Flight activity of $C$. luteus occurred mostly during summer. Even though some individuals colonized logs in spring, low flight activity during this season resulted in the absence of reproductive galleries for this species. Log incubation during summer suggests a subcortical phase between two and three months, leading to the occurrence of
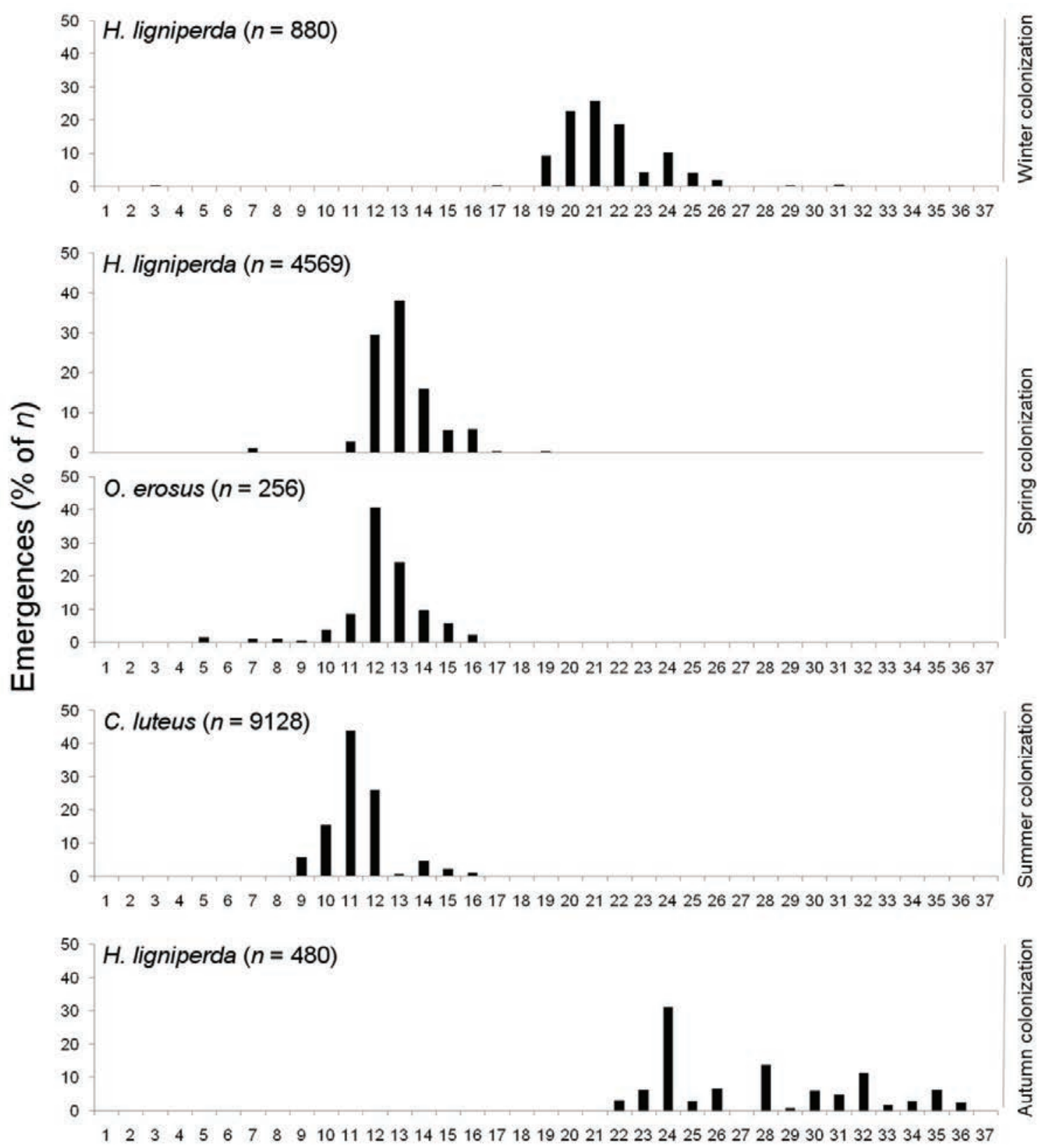

Figure 2. Weekly emergences (\% of $n$ ) from Hylurgus ligniperda, Orthotomicus erosus and Cyrtogenius luteus from the four season colonization processes. estacional.

Emergencias semanales (\% of $n$ ) de Hylurgus ligniperda, Orthotomicus erosus y Cyrtogenius luteus de los cuatro procesos de colonización 
first emergences in late summer. Flight activity during late summer and fall suggests adults looking for new breeding hosts from which a new generation will emerge in late spring and early summer. Hence, at least two generations per year would occur in Uruguay. However, the existence of a winter generation presenting low dispersion rates can only be hypothesized, provided that most aspects of the biology of $C$. luteus remain to be investigated. Despite not being considered of economic importance on its native range, $C$. luteus has been related to several infested areas in the northern region of Uruguay (Gómez et al. 2012).

Bark beetles have been related to a large number of dead trees all around the country in the last years during population outbreaks, even though they are considered secondary pests (Gómez et al. 2012, Gómez and Martínez 2013). Scolytines raise concern not only for killing several species of pine trees, but also because they are frequently associated with blue stain fungi on logs and freshly cut wood, imparting significant loss to the forestry industry (Kirisits 2004). Management of bark beetles should aim at reducing and maintaining populations at low levels, considering both preventive and mitigation measures. The availability of breeding sites is a key limiting factor for bark beetles. In implanted forests, breeding sites are installed mostly on slash material produced by pruning and thinning (Fettig et al. 2007), turning silvicultural management an essential tool for reducing bark beetle populations. Our study provided valuable information about flight activity that can be used to adjust pruning and thinning schedules by forestry companies.

\section{ACKNOWLEDGEMENTS}

We thank the forestry companies Cambium Forestal Uruguay and Weyerhaeuser Productos S.A. for the logistic help with interception traps and log exposure.

\section{REFERENCES}

Baylis NT, C de Ronde, DB James. 1986. Observations of damage of a secondary nature following a wild fire at the Otterford State Forest. South African Forestry Journal 137: 36-37.

Bentancourt CM, IB Scatoni. 2010. Guía de insectos y ácaros de importancia agrícola y forestal en el Uruguay. $3^{\text {a }}$ Edición. Montevideo, Uruguay. Hemisferio Sur. 589 p.

DIEA (Dirección de Estadísticas Agropecuarias, UY). 2013. Anuario Estadístico Agropecuario. Accessed Sep. 15. 2015. Available in www.mgap.gub.uy/diea

Eglitis A. 2001. Hylurgus ligniperda. USDA (EXFOR database pest reports). Accessed Feb. 20. 2016. Available in http:// foresthealth.fs.usda.gov/exfor/

Faccoli M, M Simonato, E Toffolo. 2012. First record of Cyrtogenius Strohmeyer in Europe, with a key to the European genera of the tribe Dryocoetini (Coleoptera: Curculionidae, Scolytinae). Zootaxa 35: 27-35.

FAO (Food and Agriculture Organization, IT). 2001. Global Fo- rest Resources Assessment 2000. Rome, Italy. FAO Forestry Paper $N^{\circ} 140.479$ p.

Fettig CJ, KD Klepzig, RF Billings, AS Munson, TE Nebeker, JF Negrón, JT Nowak. 2007. The effectiveness of vegetation management practices for prevention and control of bark beetle infestations in coniferous forests of the western and southern United States. Forest Ecology and Management 238(1-3): 24-53.

Gómez C. 2008. Principales especies de insectos forestales en plantaciones de pino de la Patagonia. Bariloche, Argentina. INTA Cuadernillo n ${ }^{\circ}$ 3. Serie Técnica: Manejo integrado de plagas Forestales. 14 p.

Gómez D. 2012. Escarabajos de corteza en Uruguay: situación actual y perspectivas. Revista INIA 30: 48-51.

Gómez D, G Martínez, RA Beaver. 2012. First record of Cyrtogenius luteus (Blandford) (Coleoptera: Curculionidae: Scolytinae) in the Americas and its distribution in Uruguay. The Coleopterists Bulletin 66: 362-364.

Gómez D, G Martínez. 2013. Bark beetles in pine tree plantations in Uruguay: First record of Orthotomicus erosus Wollaston (Coleoptera: Curculionidae: Scolytinae). The Coleopterists Bulletin 67(4): 470-472.

Haack RA. 2006. Exotic bark- and wood-boring Coleoptera in the United States: recent establishments and interceptions. Canadian Journal of Forest Research 36: 269-288.

INUMET (Instituto Uruguayo de Meterorología, UY). 2015. Estadísticas climatológicas. Accessed Mar. 26. 2016. Available in http://www.meteorologia.com.uy/ServCli/caracteristicasEstacionales

Kirisits T. 2004. Fungal Associates of European Bark Beetles with Special Emphasis on the Ophiostomatoid Fungi. In Lieutier F, KR Day, A Battisti, JC Grégoire, HF Evans eds. Bark and Wood Boring Insects in Living Trees in Europe, A Synthesis. Dordercht, The Netherlands. Kluwer Academic Publishers. 569 p.

Klasmer P, I Diez de Ulzurrún. 2013. Evaluación de la efectividad de atrayentes químicos para la captura de insectos taladradores y descortezadores de madera. In INTA ed. Primeras Jornadas Argentinas de Sanidad Forestal. Bariloche, Argentina. Libro de resúmenes. p. 53.

Mausel D, R Gara, D Lanfranco, C Ruiz, S Ide, R Azat. 2007. The introduced bark beetles Hylurgus ligniperda and Hylastes ater (Coleoptera: Scolytidae) in Chile: seasonal flight and effect of Pinus radiata log placement on colonization. Canadian Journal of Forest Research 37: 156-169.

Mendel Z. 1983. Seasonal history of Orthotomicus erosus (Coleoptera: Scolytidae) in Israel. Phytoparasitica 11: 13-24.

Reay S, P Walsh. 2001. Observations of the flight activity of Hylastes ater and Hylurgus ligniperda (Curculionidae: Scolytinae) in Pinus radiata forests in the central North Island, New Zealand. New Zealand Entomologist 24: 79-85.

Ruffinelli A. 1967. Insectos y otros invertebrados de interés forestal. Silvicultura 17: 5-79.

Ruiz C, D Lanfranco. 2008. Los escarabajos de corteza en Chile: una revisión de la situación actual e implicancias en el comercio internacional. Bosque 29(2): 109-114.

Sauvard D. 2004. General Biology of Bark Beetles. In Lieutier F, KR Day, A Battisti, JC Grégoire, HF Evans eds. Bark and Wood Boring Insects in Living Trees in Europe, A Synthesis. Dordercht, The Netherlands. Kluwer Academic Publishers. 569 p. 
Soto A, L Orengo, A Estrela. 2002. Estudio de poblaciones de insectos escolítidos (Coleoptera: Scolytidae) en las masas de Pinus halepensis Miller del Parque Natural del Montgó (Alicante). Boletín de Sanidad Vegetal. Plagas 28: 445-456.

Tribe GD. 1990. Phenology of Pinus radiata log colonization and reproduction by the European bark beetle Orthotomicus erosus (Wollaston) (Coleoptera: Scolytidae) in the south-western Cape Province. Journal of the Entomological Society of Southern Africa 53(2): 117-126.

Tribe GD. 1991. Phenology of Pinus radiata log colonization by the red-haired pine bark beetle Hylurgus ligniperda (Fa- bricius) (Coleoptera: Scolytidae) in the south-western Cape Province. Journal of the Entomological Society of Southern Africa 54(1): 1-7.

USDA (United States Department of Agriculture, US). 1993. Pest risk assessment of the importation of Pinus radiata, Nothofagus dombeyi, and Laurelia philippiana logs from Chile. Washington, USA. USDA Forest Service. Miscellaneous Publication $N^{\circ}$ 1517. 249 p.

Wood SL. 2007. Bark and Ambrosia Beetles of South America (Coleoptera: Scolytidae). UT, USA. Monte L. Bean Science Museum, Provo. 900 p.

Recibido: 08.06.16

Aceptado: 04.11.16 
